\title{
Review
}

\section{A Review of the Literature on Food Values and Their Potential Implications for Consumers' Food Decision Processes}

\author{
Opeyemi Afolabi Femi-Oladunni ${ }^{1, *}{ }^{(\mathbb{C}}$, Pablo Ruiz-Palomino ${ }^{2}\left(\mathbb{D}\right.$, María Pilar Martínez-Ruiz ${ }^{3}$ (D) \\ and Ana Isabel Muro-Rodríguez ${ }^{1}$ \\ 1 Department of Spanish and International Economy, Econometrics and Economic History, University of \\ Castilla-La Mancha, 45071 Toledo, Spain; anaisabel.muro@uclm.es \\ 2 Department of Business Administration, Faculty of Social Sciences, University of Castilla-La Mancha, \\ 16071 Cuenca, Spain; Pablo.Ruiz@uclm.es \\ 3 Department of Business Administration, Faculty of Economics and Business Sciences, University of \\ Castilla-La Mancha, 02071 Albacete, Spain; MariaPilar.Martinez@uclm.es \\ * Correspondence: Opeyemi.femi@alu.uclm.es
}

Citation: Femi-Oladunni, O.A.; Ruiz-Palomino, P.; Martínez-Ruiz, M.P.; Muro-Rodríguez, A.I. A Review of the Literature on Food Values and Their Potential Implications for Consumers' Food Decision Processes. Sustainability 2022, 14, 271. https:// doi.org/10.3390/su14010271

Academic Editor: Flavio Boccia

Received: 18 November 2021

Accepted: 24 December 2021

Published: 28 December 2021

Publisher's Note: MDPI stays neutral with regard to jurisdictional claims in published maps and institutional affiliations.

Copyright: (C) 2021 by the authors. Licensee MDPI, Basel, Switzerland. This article is an open access article distributed under the terms and conditions of the Creative Commons Attribution (CC BY) license (https:// creativecommons.org/licenses/by/ $4.0 /)$.

\begin{abstract}
This article offers a semi-systematic literature review on the concept of food values. Specifically, 36 relevant research articles were analyzed. The results underscore the novelty and rapid popularity of this concept in different professional, scientific, and academic fields. Among the findings, the article highlights how the concept of food values has evolved to accommodate the features and behaviors of specific markets. Nonetheless, one can group food values into three distinct clusters. This article expands our understanding on the evolution of food values along different dimensions (various clusters and segments related to geographic regions and social classes). It also identifies several research gaps and translates them into different research proposals.
\end{abstract}

Keywords: food values; food sector; consumer behavior; semi-systematic review

\section{Introduction}

The food sector-one of the largest sectors in world economies-encompasses a complex network of activities related to the supply, consumption, and catering of food services. As one of the world's most dynamic sectors, food undoubtedly plays a key role in the economic development of any nation [1,2]. In this regard, it is important to highlight the variables that influence consumers' food-related decision-making processes. Indeed, businesses in the sector need to properly tailor their products, marketing strategies, and business models around consumers' constantly changing needs, desires, and demands. For this reason, one whole research stream is devoted to assessing how consumers behave in response to operators' food strategies [3-6]. Research in this domain has shown that companies must continuously try to acquire a deeper understanding of certain variables, such as food values, that are key to consumers' food purchasing decisions $[4,7,8]$.

In general, different values hold diverse significance depending on the segment of the market [9]. People make decisions based on a complex interaction of, among other variables, values, personal identities, beliefs, social norms, traditions, emotional state, and environmental pressures. In this vein, the concept of food values, first proposed by Lusk and Briggeman [4], offers a useful framework for understanding these decisions. Their work represents a landmark contribution in the relevant literature. The authors proposed a food values scale, which expresses abstract attributes that can explain consumer purchases over time. According to this view, consumers base their product choices on a set of inferred food values, which often encompasses numerous physical attributes simultaneously, such as naturalness, taste, price, safety, convenience, nutrition, origin, fairness, tradition, appearance, and environmental impact. Lusk and Briggeman's [4] work led to an influx of academic papers that have investigated the concept of food values from 
various perspectives. Some of those papers, for example, [10,11], have even proposed additional food values to complement Lusk and Briggeman's [4] original list.

Given the array of research on this topic, we believe there is value in reviewing the concept of food values and codifying its current status in the literature. Thus, this article performed a semi-systematic review of the concept in order to gain deeper insights into the evolution of food values relative to several dimensions, such as geographic regions and social classes. Our hope is that this review will identify research gaps (for academics) and will facilitate improved segmentation strategies (for practitioners).

This paper is organized as follows: In Section 2, we describe our method for reviewing the literature on food values. In Sections 3 and 4, we respectively report and discuss our results. Finally, Section 5 concludes the paper and Section 6 outlines the theoretical implications alongside some future research avenues.

\section{Semi-Systematic Review of the Literature}

A literature review can take two forms: (i) serving as the background for an empirical study and (ii) acting as a stand-alone piece [12]. A background review is utilized as justification for choices made in research design, as well as to give hypothetical context or recognize a gap in the literature that the study plans to fill [13]. The goal of a stand-alone review is, however, to produce a thorough collection of the most relevant studies by aggregating, interpreting, explaining, and integrating material from the existing literature [14]. To this end, we will follow the three-stage guidelines postulated by the previous research [15], namely: (1) planning, (2) conducting, and (3) reporting the results.

\subsection{Planning Stage of the Review}

We planned the review according to the convention described in Table 1. We chose this method because it provided a robust set of guidelines but was flexible enough to accommodate changes to the process.

Table 1. Review Convention.

\begin{tabular}{ll}
\hline Step & Description \\
\hline Research question & $\begin{array}{l}\text { How do the papers and studies of the existing literature approach } \\
\text { the concept of food values? }\end{array}$ \\
\hline Population Targeted & $\begin{array}{l}\text { Papers related to food values in marketing, management, and } \\
\text { related areas. }\end{array}$ \\
\hline Search Strategy & Databases: Web of Science (WoS), Scopus. \\
\hline Inclusion criteria & Language: English; Years of publication: 2009-2021. \\
\hline Exclusion criteria & $\begin{array}{l}\text { Duplicated papers (found in more than one database). } \\
\text { Papers that discuss the food value chain (discussions that involve } \\
\text { the actions and role of a network of stakeholders). } \\
\text { Papers that discuss food values through the concept of food } \\
\text { nutrient components (e.g., carbohydrates, protein, fats, and } \\
\text { oil, etc.). }\end{array}$ \\
\hline Data analysis & $\begin{array}{l}\text { Descriptive analysis. } \\
\text { Content analysis. }\end{array}$ \\
\hline Expected results & $\begin{array}{l}\text { Overview of the literature on food values. } \\
\text { Summary of papers. } \\
\text { Future research agenda. }\end{array}$ \\
\hline
\end{tabular}

\subsection{Conducting Stage of the Review}

In this stage, we applied the following criteria to the Web of Science (WoS) and Scopus databases: The articles had to be published in English between 2009 and 2021. We used 2009 as the earliest publication year to align with the release of Lusk and Briggeman's [4] landmark contribution. Next, turning to keywords, we need to note that searching for "food 
values" also exposed papers dealing with the agricultural food value chain. We excluded such papers because our review was focused on food values that influence consumers' food purchase decisions, rather than the actions and roles of a network of stakeholders (from farm to industry) in the food production system. Note that we used evidence-based preferred reporting items for systematic reviews and meta-analyses (PRISMA) to refine the data (Figure 1).
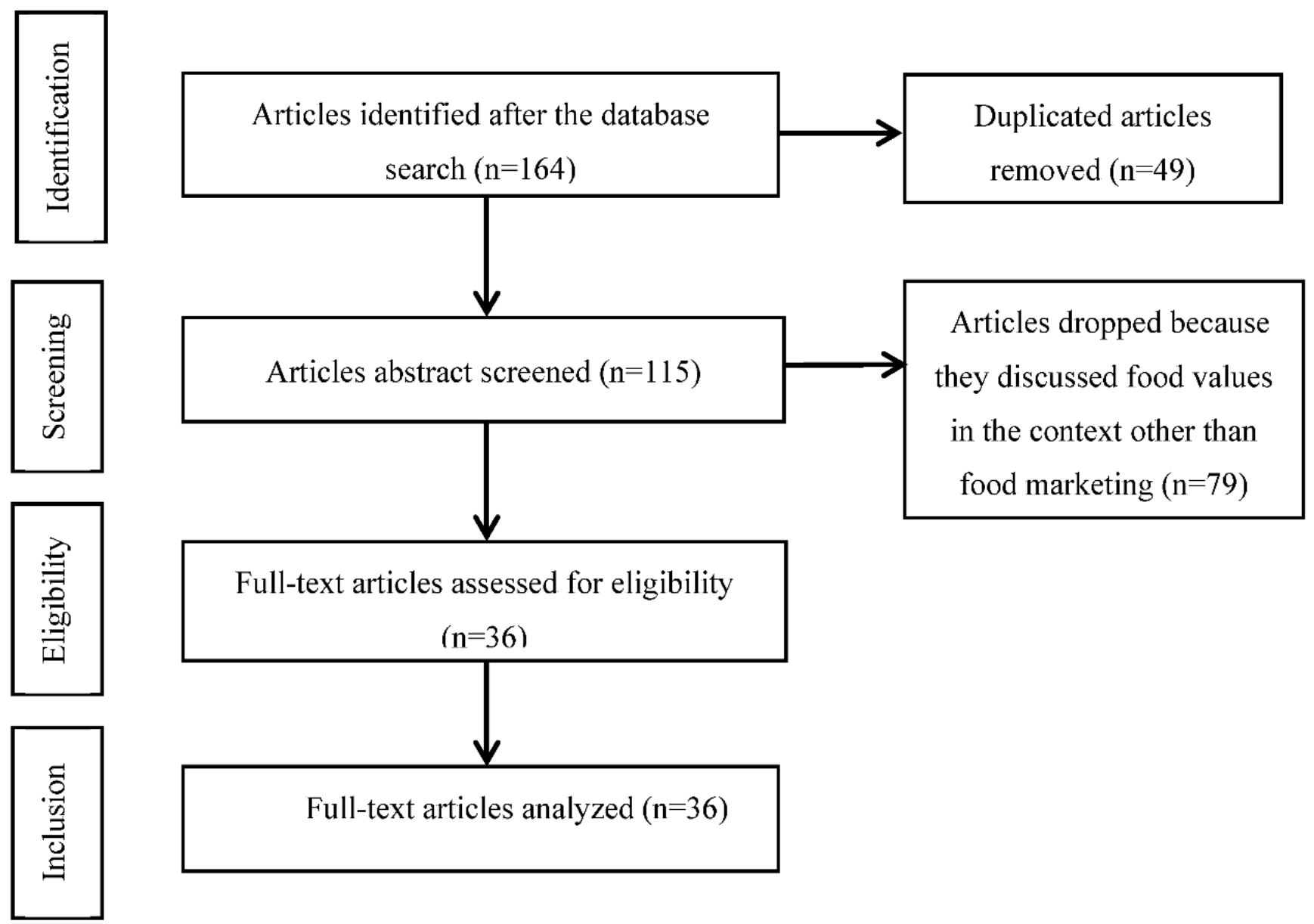

Full-text articles assessed for eligibility

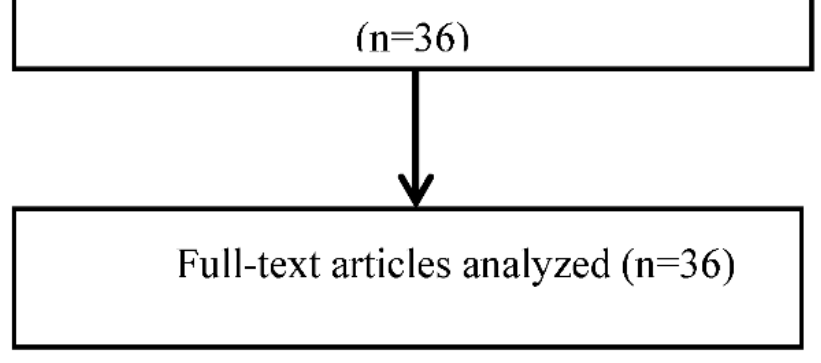

Figure 1. Methodological steps for the choice of relevant papers based on PRISMA.

\section{Reporting and Dissemination of Results}

From the data obtained, we focused on the following variables: year of publication, publication outlet, research method, explored behaviors, geographical scope, and main results.

\subsection{Year of Publication}

Between 2009 and 2021, we identified 36 papers that were in the same research line as Lusk and Briggeman [4], (i.e., they all focused on a stable set of meta-attributes that influence consumer food purchase decisions). Most of these papers were published between 2019 and 2020: the highest yearly total, eight articles, were published in the year 2020 (see Figure 2). 


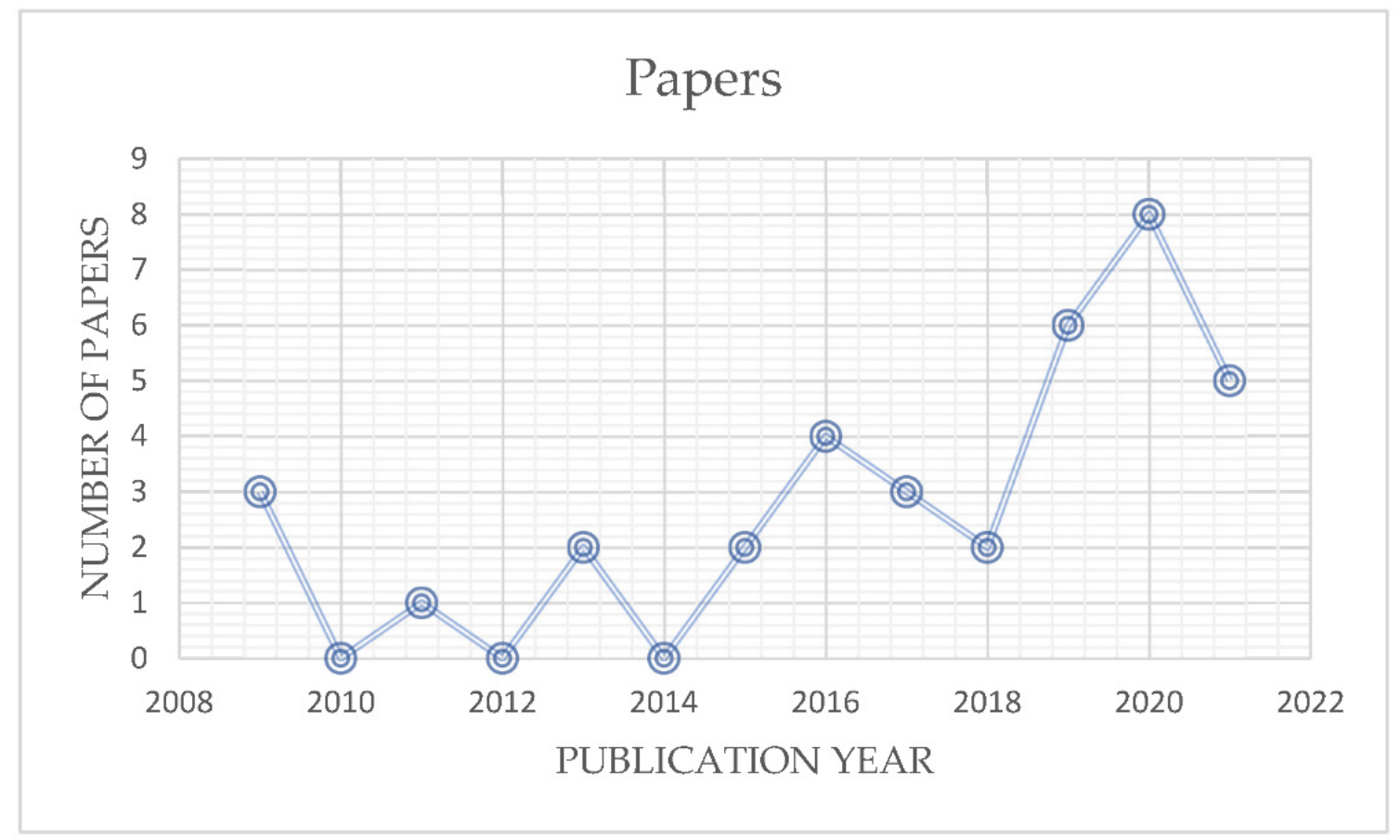

Figure 2. Full-text articles analyzing food values influencing consumers' decision processes.

\subsection{Publication Outlet}

The analyzed papers were published in 27 different publication outlets (Table 2), which illustrates a diffusion across different sources. The British Food Journal and the journal of Food Quality and Preference each had the highest number of papers (four), followed closely by the Foods, Appetite, and Sustainability journals (two each), with other journals publishing one paper each. Furthermore, all (except two of them) of the papers analyzed according to the Journal Citation Report (JCR) published by Clarivate, cut across the fields of "economics", "agricultural economics \& policy", "nutrition \& dietetics", "behavioral sciences, food science \& technology", "hospitality, leisure, sport \& tourism", "management", "public, environmental \& occupational health", "education, scientific disciplines", "agriculture multidisciplinary", "environmental studies", "green \& sustainable science \& technology", "psychology", and "environmental sciences". All articles were indexed in the Science Citation Index Expanded (SCIE), Social Sciences Citation Index (SSCI), and Emerging Sources Citation Index (ESCI) (see Table 2).

Table 2. Publication outlet, country, and research focus.

\begin{tabular}{|c|c|c|}
\hline $\begin{array}{c}\text { Acta Universitatis } \\
\text { Agriculturae et Silviculturae } \\
\text { Mendelianae Brunensis }{ }^{\text {a }}\end{array}$ & Czech Republic & - \\
\hline $\begin{array}{c}\text { American Journal of } \\
\text { Agricultural Economics }\end{array}$ & USA & $\begin{array}{l}\text { Agricultural Economics \& } \\
\text { Policy/Economics }\end{array}$ \\
\hline Appetite (2)**,ab & Denmark, Spain & $\begin{array}{c}\text { Nutrition \& } \\
\text { Dietetics/Behavioral Sciences }\end{array}$ \\
\hline $\begin{array}{c}\text { Applied Economic } \\
\text { Perspectives and Policy }\end{array}$ & USA & $\begin{array}{l}\text { Economics/Agricultural } \\
\text { Economics \& Policy }\end{array}$ \\
\hline British Food Journal (4) ${ }^{* *, a b}$ & Spain (2), No region, Taiwan & $\begin{array}{l}\text { Agricultural Economics \& } \\
\text { Policy/Food Science \& } \\
\text { Technology }\end{array}$ \\
\hline
\end{tabular}


Table 2. Cont.

\begin{tabular}{|c|c|c|}
\hline $\begin{array}{c}\text { Canadian Journal of } \\
\text { Agricultural Economics ab }\end{array}$ & Canada & $\begin{array}{l}\text { Economics/Agricultural } \\
\text { Economics \& Policy }\end{array}$ \\
\hline $\begin{array}{c}\text { European Review of } \\
\text { Agricultural Economics }\end{array}$ & USA * and Norway * & $\begin{array}{l}\text { Economics/Agricultural } \\
\text { Economics \& Policy }\end{array}$ \\
\hline $\begin{array}{l}\text { Food Quality and } \\
\text { Preference (4) }{ }^{* *, a b}\end{array}$ & $\begin{array}{c}\text { USA, Italy, China * and Japan } \\
\text { *, Taiwan *, } \\
\text { Indonesia * }\end{array}$ & Food Science \& Technology \\
\hline Foods $(2) * *, a b$ & Mexico, Japan & Food Science \& Technology \\
\hline Frontiers in Psychology $a b$ & No region & Psychology \\
\hline $\begin{array}{c}\text { International Food Research } \\
\text { Journal } \mathrm{ab}\end{array}$ & Thailand & Food Science \& Technology \\
\hline $\begin{array}{l}\text { Journal of Destination } \\
\text { Marketing \& Management }\end{array}$ & Taiwan & $\begin{array}{l}\text { Hospitality, Leisure, Sport \& } \\
\text { Tourism/Management }\end{array}$ \\
\hline $\begin{array}{c}\text { Journal of Economic Behavior } \\
\text { and Organization }{ }^{b}\end{array}$ & USA & Economics \\
\hline $\begin{array}{l}\text { Journal of Food and Nutrition } \\
\text { Research }^{\mathrm{b}}\end{array}$ & No region & Food Science \& Technology \\
\hline $\begin{array}{c}\text { Journal of Food Science and } \\
\text { Technology } b\end{array}$ & Tunisia & Food Science \& Technology \\
\hline $\begin{array}{c}\text { Journal of Hunger \& } \\
\text { Environmental Nutrition ab }\end{array}$ & USA & $\begin{array}{l}\text { Public, Environmental \& } \\
\text { Occupational Health }\end{array}$ \\
\hline $\begin{array}{l}\text { Journal of International } \\
\text { Consumer Marketing ab }\end{array}$ & Iran * and USA * & Business \\
\hline $\begin{array}{l}\text { Journal of Nutrition } \\
\text { Education and Behavior } b\end{array}$ & Netherland & $\begin{array}{c}\text { Education, Scientific } \\
\text { Disciplines/Nutrition \& } \\
\text { Dietetics }\end{array}$ \\
\hline $\begin{array}{c}\text { Journal of Travel \& Tourism } \\
\text { Marketing ab }\end{array}$ & China & $\begin{array}{c}\text { Hospitality, Leisure, Sport \& } \\
\text { Tourism }\end{array}$ \\
\hline Meat Science $^{\mathrm{ab}}$ & No region & Food Science \& Technology \\
\hline Nutrients ${ }^{a b}$ & (Athletes from 69 countries) & Nutrition \& Dietetics \\
\hline Nutrition ${ }^{a b}$ & Australia & Nutrition \& Dietetics \\
\hline Public Health Nutrition ${ }^{a b}$ & USA & $\begin{array}{c}\text { Public, Environmental \& } \\
\text { Occupational } \\
\text { Health/Nutrition \& Dietetics }\end{array}$ \\
\hline Quality- Access to Success ${ }^{a}$ & Italy & - \\
\hline $\begin{array}{l}\text { Renewable Agriculture and } \\
\text { Food Systems }{ }^{a b}\end{array}$ & USA & Agriculture Multidisciplinary \\
\hline $\begin{array}{l}\text { Review of Agricultural } \\
\text { Economics ab }\end{array}$ & Vietnam & $\begin{array}{l}\text { Economics / Agricultural } \\
\text { Economics \& Policy }\end{array}$ \\
\hline Sustainability $(2)^{* *, a b}$ & Spain, Mexico & $\begin{array}{c}\text { Environmental Studies/Green } \\
\text { \& Sustainable \& } \\
\text { Technology/Green \& } \\
\text { Sustainable Science \& } \\
\text { Technology/Environmental } \\
\text { Sciences }\end{array}$ \\
\hline
\end{tabular}

Notes: *: The countries are comparatively investigated; **: Numbers in parenthesis are the number of papers from the publication outlet. No region: The research did not specify a focal country or it was a review/concept paper.

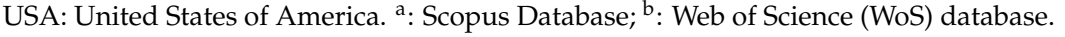




\subsection{Research Methods}

The majority $(n=28)$ of the papers utilized a survey to carry out a quantitative empirical analysis to quantify behaviors and make generalizations from the studied populations. Fewer of them utilized a mixed-method (both qualitative and quantitative) or qualitative analysis ( 1 and 4 , respectively). Only one paper was conceptual, while two others were listed as review papers.

\subsection{Explored Behaviors}

The papers measured consumers' willingness to pay, willingness to buy, stated and revealed preferences for organic food, responses to food nanotechnology, and post-purchase behavior. Most of them focused on specific groups of people (e.g., gardeners, migrants, university students, households, tourists, organic product consumers, egg consumers, athletes, and meat consumers) and specific markets (e.g., fast food restaurants, grocery stores, meat processing markets, and vegetable markets). While some of the papers measured consumers' traits, some were review papers that provided insight into the literature. There was also a concept paper that illustrated an alternative approach to viewing and assessing food values.

\subsection{Geographical Scope}

Most of the papers focused on the Americas (United States of America, Latin America, and Canada), Asia, Europe, and the Middle East. The highest number of countries were from Asia (seven: China, Indonesia, Iran, Japan, Taiwan, Thailand, and Vietnam), followed by five countries from Europe (Czech, Netherland, Norway, Spain, and Italy,), one country from Latin America (Mexico), two from North America (Canada and the United State of America), and one from the Middle East (Tunisia).

\subsection{Main Results of the Papers}

We summarized the main results of these papers in accordance with the four categories of research methods that were noted earlier. The subject matter "food values" appears to have been discussed using concept papers and review papers. In addition, qualitative and quantitative analysis techniques have been utilized to disseminate the existing knowledge.

The conceptual paper by Dagevos and van Ophem [16] provided a consumer-centered conceptual framework to elucidate the sets of food values as postulated by Lusk and Briggeman [4]. Their framework sorted values into four types: product values (values such as safety, nutrition, price, convenience, taste, texture, and other sensory properties of the product), process values (consumers' interest in the practices and processes of the food production, such as environmental impact and naturalness), location values (the location where the food is being purchased) and emotional values (feel-good factors such as experience, novelty, etc.). Among the review papers, Martinez-Ruiz and Gomez-Canto [6] analyzed the most important external influences that consumers may encounter in food shopping environments. With a spotlight on the COVID-19 pandemic and the meat supply sector, Hobbs [17] highlighted that consumers' underlying influences may shape their reaction to vulnerability during a pandemic, which is a lesson for food manufacturers looking to proactively delineate the weaknesses inside their production framework.

Adopting the consumer-centered framework of Dagevos and van Ophem [16], Liñán, Arroyo, and Carrete [18] applied a qualitative thematic approach to uncover that consumers' conceptualization of good food is tricky, imprecise, and instinctive. The authors further suggested that consumers use utilitarian qualities, such as product and process values, to evaluate how good the food is. In any case, the location value and emotional values additionally impact the food inclinations of consumers. Unlike Liñán et al. [18], who grounded their qualitative approach in a consumer-centered framework, Beavers, Atkinson, and Alaimo [19] focused on a group of vegetable gardeners to discuss what values influenced their decision to harvest more vegetables from their gardens rather than purchase them from the grocery store. The majority of the gardeners noted the freshness 
and taste of the vegetables they grew through organic cultivation (reflecting values such as environmentally friendly and naturalness), coupled with their desire to adopt the culture of vegetable gardening and avoid wasting vegetables, led to an increased intake of harvested vegetables.

In other research [20], a mixed-method (quantitative-qualitative) approach was conducted to analyze the values and opinions toward food among Danish consumers of organic products compared to conventional consumers of local products [20]. This work showed that both groups of consumers were associated with the values of taste, purity, diversity, authenticity, and ethical concerns toward food. However, the consumers of organic products differed by including environmental effects as an influence on their food choices.

The papers that used the quantitative empirical approach achieved variable results with regard to food value preferences, which might imply that said preferences are regionspecific and should not be generalized. For example, Bazzani et al. [11] proposed that the tradition value should be dropped from Lusk and Briggeman's [4] list due to the concept of tradition being interpreted very differently among groups of people; however, the authors also identified some common ground among people: for instance, respondents in the United States and Norway both listed the safety value as the most important, while outlining the convenience and novelty values as the least important. In a similar comparison of North American and Iranian respondents, Shahriari et al. [21] deviated from Lusk and Briggeman [4] and Bazzani et al. [11] by finding that the strongest predictors of attitude toward purchasing organic food were naturalness in the US and price in Iran. Likewise, other authors [22] found that consumers ranked taste, nutritional value, price, and appearance as more influential over their purchasing decisions than sustainability attributes related to production and origin.

Some studies focused solely on the United States, unlike the comparative studies discussed in the preceding paragraph. For instance, Lusk [23] focused on organic eggs and milk consumers, and noted that consumers are relatively more concerned about the environmental impact; tradition created a higher demand for organic milk and eggs relative to non-organic milk and eggs though. This may imply that organic food products are more traditional and environmentally friendly, and, still in the strain of a sole study on US consumers' behavioral preferences, Lusk [24] explored consumers' behavioral preferences of food values concerning changes and instability of income. His findings revealed that the relationships with preference reversals are strongest for the food values of price and novelty, thus implying that the price and novelty values were the most susceptible to changing importance in the wake of income instability among the population studied [24].

Another piece of research [25], which focused on the United States, looked at the concept of food values and consumer behavior from a different perspective other than US-based research. He focused on Mexicans in the US and assessed how acculturation (in specific, language use) influenced food value preferences. He showed that food values vary based on participants' language use, as English speakers were far more likely than Spanish speakers to report that convenience is a very important reason for preferring fast food to home cooking; Spanish-speaking participants placed greater importance on price, nutrition, ease of preparation, and food longevity when choosing between food items. These findings could be questioned due to the economic differences that may arise between English speakers and Spanish speakers, thus making income an important factor [25]. However, this research was more interested in the role of language as a proxy for the adoption of the US culture [25]. Finally, during the COVID-19 pandemic, research on US consumers as a whole revealed that food values seemed genuinely stable in the initial phases, but a statistically significant decrease in the price and nutrition values underscored the tradeoffs made by families [26].

In the north of America, another study [27] revealed that Canadian consumers emphasized taste, safety, nutrition, and price as the most preferred food values in relation to nanotechnology foods. In Mexico, other scholars focused on the behavioral attitudes of 
fast food consumers $[28,29]$ and found that food values and positive anticipated emotions impacted people's attitudes toward the brand, which then impacted consumers' purchase intentions. In their studies, it was revealed that the positive anticipated emotions exerted a greater impact than food values, thus suggesting that the best method of boosting purchase intention is by improving attitude toward the brand rather than attitude toward eating a hamburger $[28,29]$. In general, it was observed that fast food consumers assigned more importance to the hedonic than to the utilitarian benefits of food [28,29].

There is a study that explains how food values and other variables related to dietary acculturation influence purchasing decisions of foreign students in Spanish universities [30]. This study revealed that, although these factors had a significant influence on purchasing decisions, there were some differences depending on the geographical origin of foreign students. Thus, European students showed a greater propensity to value sustainable production practices in their food choices, while American students placed greater emphasis on taste. In another study in Spain, consumers could be clustered into three groups based on their assessment of food values, namely, utilitarian (those who place importance on the price of food and attach considerable value to appearance and taste), hedonic (those who highly value all aspects except for price), and ethical groups (those who are the least concerned with the price, taste, and appearance but emphasize naturalness, nutrition, origin, tradition, environmental impact, safety, and fairness) [31]. Hence, these groups of consumers not only demonstrated diverse habits but also differed on variables such as satisfaction, trust, and loyalty. On the other hand, another study on Spanish consumers evaluated the effect of food values on post-purchase consumer behavior and confirmed that they do influence postpurchase consumer behaviors such as satisfaction and loyalty, regardless of the nuances displayed within groups [32]. Furthermore, in another country in the South of Europe, Italy, some authors in their case studies found that some consumers who are significantly influenced by values such as the taste, safety, appearance, and origin, are more willing to pay for food products fortified with special ingredients that possess advantageous physiological effects [33,34]. In another study focused on the Czech Republic, consumers were revealed to devote more attention to the nutritional value and the composition, as well as the food's origin [35]. To conclude the discussion of the studies in Europe, during the COVID-19 pandemic, a quantitative article from Spain [36] revealed that among grocery store consumers, food values have a positive and significant influence on non-financial results such as satisfaction and loyalty.

Finally, regarding the continent of Asia, one paper used a Japanese case study to reveal the behavior of consumers' purchase intent after a disaster [37]. Their findings showed that, for Japanese consumers, the social value of food generated better attitudes than the safety value toward purchase intention. In Thailand, the most influential food values were nutrition, assurance, storytelling, and taste, in that order [38]. In Hong Kong, other authors used the video clip technique to compare food value preferences between Generation $Y$ and other generations to identify its effectiveness in promoting food tourism. [39]. Their research also revealed that the appearance (in this case, attractiveness) and intercontinental knowledge of the food were the most significant values in explaining the behavioural involvement, familiarity, and intention to visit Hong Kong for food tourism. They also found that for respondents who were categorized as Generation Y, the "realistic restaurants" value had a significant effect on their behavioral involvement, unlike other generations for whom that value did not have an effect on their behavioral involvement [39]. Finally, in a comparative study of imported fruit preferences between Japan, Taiwan, and Indonesia, food safety certification and freshness appeared to be the first and second most important food values for the majority of those consumers [40]. To conclude, in a case study focused on the contingent of Australia (Oceania), the authors showed that university students treated taste, cost, and convenience as the greatest determinants of food choice [41].

In summary, the selected papers show how food values can be used to generate novel insights into consumers' behavioral choices, which can then help guide the strategic posi- 
tioning of food producers and marketers. Such knowledge can also benefit policymakers who want to achieve the United Nations' sustainable development goals.

\section{Discussion}

Lusk and Briggeman [4] made a landmark contribution to the literature with their efficient method of quantifying consumer preferences for certain food attributes over others. In this manner, they reoriented research around the arrangement of a food values scale: a stable set of beliefs regarding the relative importance of the meta-attributes, consequences, and desired end-states related to buying and consuming food. Since then, other authors from the fields of agricultural economics and business strategy have expanded on their framework, refining the list of values through research on distinct geographical areas and consumer segmentations.

From the literature review, we discerned that these food values can be categorized into clusters (Figure 3). We identified three clusters, each with specific sub-groups of attributes or values. Cluster 1 has three sub-groups: (i) credence attributes, which are classified as food values that consumers have the least knowledge about (such as naturalness, safety, environmental impact, origin, animal welfare, nutrition, and fairness); (ii) experience attributes, which are classified as taste, appearance, convenience, and novelty; (iii) the price attribute, which mainly refers to price. Cluster 2 also has three sub-groups: (i) beneficial values, which are classified as taste, price, nutrition, seasonality, appearance, naturalness, and convenience; (ii) social values, which are classified as restoration, employment creation, rural fishery culture protection, origin, and environment; (iii) safety values, which are classified as food inspection institutions and methods. Finally, cluster 3 has four sub-groups: (i) product values, which are classified as texture, color, freshness, taste, flavor, safety, nutrition, price, and convenience; (ii) process values, which are identified as environmental impact, naturalness, and animal welfare; (iii) location values, which refer to where the food was purchased; (iv) emotional values, which refer to feel-good factors such as novelty and experience. 


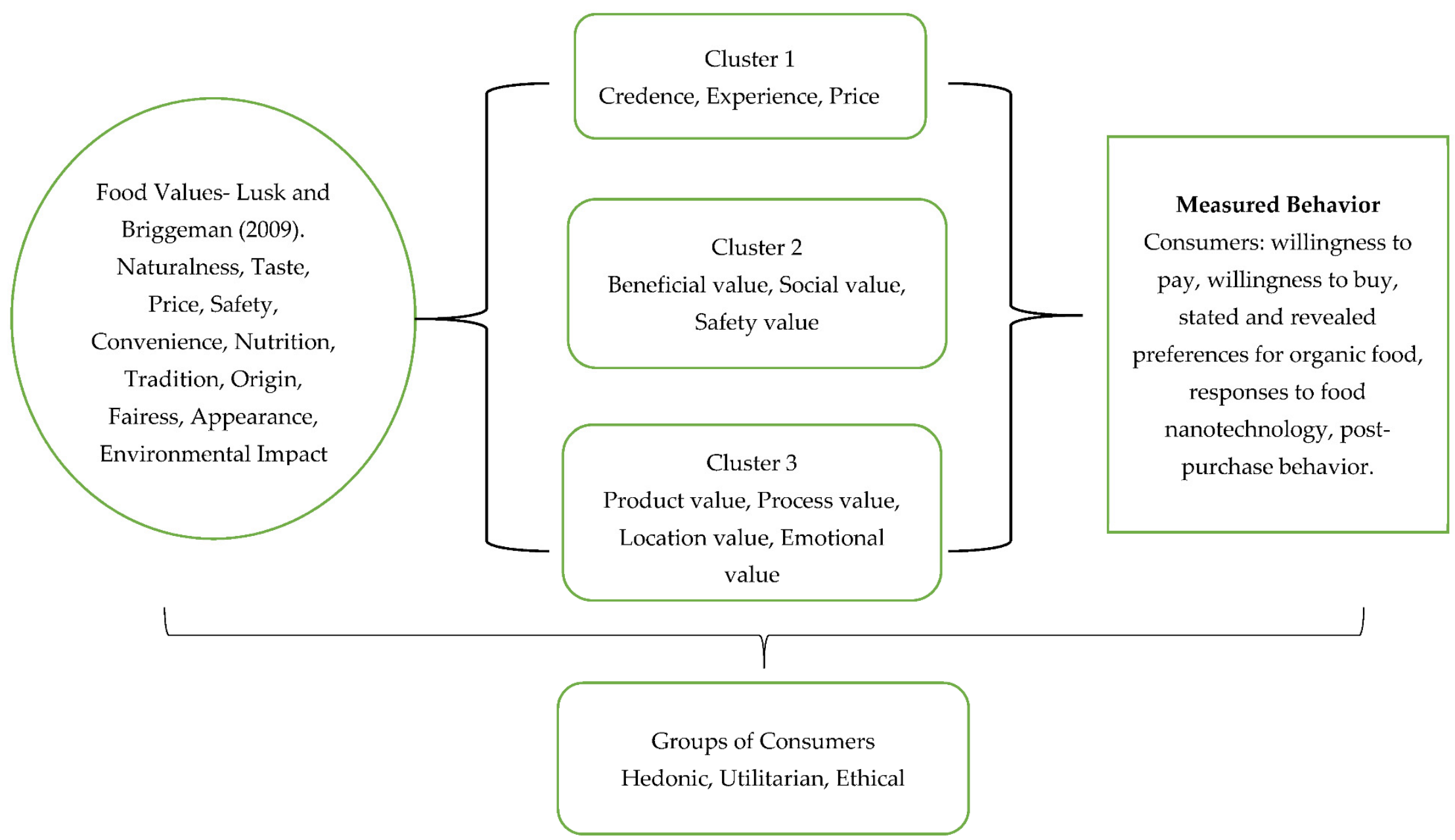

Figure 3. Food Value Clusters and Measured Behavior. (Notes: Cluster 1- Credence, Experience, Price [11]; Cluster 2—Beneficial value, Social value, Safety value [37]; Cluster 3-Product Value, Process Value, Location Value, Emotional Value [16]. Consumer Groups: Hedonic Values, Utilitarian Values, Ethical Values [31]). 
Finally, the usage of these food values in clusters can be objective because they can also be used to answer questions regarding (a) willingness to buy, (b) willingness to pay, (c) stated and revealed preferences of organic food, (d) responses to food nanotechnology, and (e) post-purchase behavior, without having them in clusters. This is dependent on the objectives and aims of researchers. Based on our review, scholars can align consumers' behavioral patterns with the consumer segments (e.g., hedonic, utilitarian, ethical) to which each of them belongs [31] while controlling for their food value preferences in clusters. Hence, this will improve the position of food policymakers, producers, and marketers.

\section{Conclusions}

Since the key food values scale proposal by Lusk and Briggeman [4], different scholars have tried to refine and extend it. Seeking to synthesize the evolution of this concept, the present article reviewed existing evidence about the influence of food values on consumers' food buying behavior. To this end, we conducted a semi-systematic literature review, using the evidence-based preferred reporting items for systematic reviews and meta-analysis (PRISMA) to guide our review of 36 articles that met our inclusion criteria.

From the sampled papers, we concluded that the concept of food values has been investigated in several formats and across different target groups (e.g., different generations, geographic regions, and social classes). Researchers have also examined consumer behavior across different markets and different food types while controlling for the effects of disasters or pandemics. Evidently, there are a few cross-region consistencies in terms of consumer behavior stemming from food value preferences. Therefore, it is important to evaluate region-specific characteristics and segmentations. That said, we did find that food values generally occur in clusters. For instance, the credence cluster encompasses the values of experience, price, beneficial, social, safety, product, process, location, and emotion. Furthermore, these values can be used to group customers into three segments: hedonic, utilitarian, and ethical. Of course, the application of these clusters and segments depends on researchers' target regions and questions of interest.

To the best of our knowledge, this review is one of the first studies to assess the evolution of the food values concept. It is not surprising then that the applications of this research are numerous and diverse. Among others, these include new foods' development, food manufacturing, and selling. There is no doubt that this greater knowledge about food values can enhance all of the processes, operations, and activities included in the complete value chain.

While a myriad of fields have investigated this concept-ranging from economics to nutrition and green technology - the bulk of the literature revolves around developed economies. Hence, this article calls for further research that focuses on emerging markets, whose demographic characteristics will likely lead to different consumer behavioral dynamics. In this way, scholars can enhance the conversation around emerging economies and, thereby, improve the position of food policymakers, producers, and marketers in those areas.

\section{Theoretical Implications}

The relevant literature on food values has been able to explain, among other things, consumer behavior toward the willingness to pay, willingness to buy, stated and revealed preferences for organic food, responses to food nanotechnology, and post-purchase behavior. While scholars have delineated the most and least preferred food values in developed nations, our review highlights the need to explore the impact of food values in emerging economies that are characterized by more economic instability and vast cultural diversity. Such investigations would help illuminate the differences between sociodemographic groups. This leads to our first proposition for future research: 
Proposition 1. Do food values vary across sociodemographic characteristics such as ethnicity, country of origin, age, and estimated income?

As a follow-up, it would be interesting to consider the role played by the well-known Engel's [42] theory, which posits that as income rises, the proportion of income spent on food decreases, while the percentage of income budgeted for other goods (e.g., luxury items) increases. At the same time, consumers are more likely to extend their eating regimens and request a more noteworthy assortment as their incomes increase, e.g., [43,44]. Indeed, the rising variety of food decisions is commonly perceived as reflecting consumers' expanded capacity for discovering food sources that fit their inclinations. Thus, a question remains: Will the preferential ranking of these sets of food values remain stable when income improves or declines? Hence, we propose:

Proposition 2. Will food values that influence consumer purchase decisions inversely react to an increase in income?

On a similar point, food price inflations have an impact on some consumers more than others based on income levels. Additionally, consumers may exhibit a more rapid response to food inflation in relation to luxury food items (e.g., with feel-good factors such as experience, novelty, and convenience) than to staples foods [45]. As such, understanding the impact of changes in the food price index on food values could be a significant discussion among academics, policymakers, and food producers. Hence, we propose:

Proposition 3. Do consumers shift their food values in response to increasing/decreasing food price index"?

Of course, producers are challenged to adapt their products to consumers' constantly changing necessities and desires. In this vein, the web and online media have enabled producers to impart information to and co-create new products with consumers. With co-creation becoming a viable business strategy for improving consumers' experience, consumers unreservedly give significant, unique, new, and practical thoughts that can foster product advancement and trigger innovation [46]. This leads us to our fourth proposition:

Proposition 4. Will food producers maintain a competitive advantage that will aid business success if consumers' food values take a position of priority in the co-creation process?

Based on the authors of [31] finding that consumers' food values can be used to identify segmentations (hedonic, utilitarian, or ethical), we can also propose the following:

Proposition 5. Could consumers oriented around hedonic, utilitarian, and ethical values change their category when the food price index and estimated income violate the ceteris paribus assumption?

Finally, considering that past behavior predicts subsequent behavior [47], studies of food values should incorporate a historical dimension. Thus, our sixth proposition is:

Proposition 6. Can food values that influence purchase decisions in a past occurrence be used to predict consumers' subsequent behavioral patterns?

\section{Future Research}

The food sector plays a key role in achieving a significant number of the sustainable development goals (SDG) [48,49] and even with greater emphasis on developing countries. However, as previously stated, the factors that influence food purchase decisions have been largely under-researched in developing economies. This paper outlines the general suggestions for food researchers in emerging economies to analyze, firstly, the most and 
least appreciated food values in the food market, and secondly, whether these food values change in importance relative to the consumer price index. Likewise, in light of Engel's theory [42] in mind, future research could investigate whether food values remain stable relative to changes in household income and food expenditures. Fourthly, future research could evaluate the effect of food values on pre- and post-purchase behavior, as well as product co-creation. Fifthly, future studies should analyze whether there are distinct disparities between hedonic, utilitarian, and ethical values in terms of consumers' behaviors. Finally, we also strongly believe that future research should determine whether past food values can predict subsequent behavioral patterns.

Author Contributions: Conceptualization, O.A.F.-O., P.R.-P. and M.P.M.-R.; methodology, O.A.F.O., P.R.-P. and M.P.M.-R..; software, O.A.F.-O.; validation, P.R.-P., M.P.M.-R. and A.I.M.-R.; formal analysis, O.A.F.-O., P.R.-P.R, M.P.M.-R. and A.I.M.-R.; investigation, O.A.F.-O., P.R.-P., M.P.M.-R. and A.I.M.-R.; resources, O.A.F.-O., P.R.-P., M.P.M.-R. and A.I.M.-R., data curation, O.A.F.-O., P.R.-P. and M.P.M.-R.; writing—original draft preparation, O.A.F.-O., P.R.-P., M.P.M.-R. and A.I.M.-R..; writingreview and editing, O.A.F.-O., P.R.-P., M.P.M.-R. and A.I.M.-R.; visualization, P.R.-P., M.P.M.-R. and A.I.M.-R.; supervision, P.R.-P., M.P.M.-R. and A.I.M.-R.; project administration, O.A.F.-O., P.R.-P. and M.P.M.-R.; funding acquisition, M.P.M.-R. All authors have read and agreed to the published version of the manuscript.

Funding: No Funding was received for this study.

Institutional Review Board Statement: Not applicable.

Informed Consent Statement: Not applicable.

Data Availability Statement: Not applicable.

Acknowledgments: The authors of this article declare the research was conducted in the absence of any financial or commercial relationships that could be construed as potential conflicts of interest.

Conflicts of Interest: The authors declare no conflict of interest.

\section{References}

1. Eccles, R.G. The Importance of the Food and Beverage Sector for the Sustainable Development Goals, Forbes. Available online: https:/ / www.forbes.com/sites/bobeccles/2018/07/29/the-importance-of-the-food-and-beverage-sector-for-the-sustainabledevelopment-goals/?sh=536da0ef7bdf (accessed on 10 December 2021).

2. Sadiku, M.N.O.; Musa, S.M.; Ashaolu, T.J. Food Industry: An Introduction. Int. J. Trend Sci. Res. Dev. 2019, 3, 128-130. [CrossRef]

3. Garber, L.L.; Hyatt, E.M.; Starr, R.G. Measuring consumer response to food products. Food Qual. Prefer. 2003, 14, 3-15. [CrossRef]

4. Lusk, J.L.; Briggeman, B.C. Food values. Am. J. Agric. Econ. 2009, 91, 184-196. [CrossRef]

5. Logue, A.W. The Psychology of Eating and Drinking, 4th ed.; Routledge: New York, NY, USA, 2015.

6. Martinez-Ruiz, M.P.; Gomez-Canto, C.M. Key external influences affecting consumers decisions regarding food. Front. Psychol. 2016, 7, 1618. [CrossRef] [PubMed]

7. Botonaki, A.; Mattas, K. Revealing the values behind convenience food consumption. Appetite 2010, 55, 629-638. [CrossRef]

8. Recordati, G.B.P. The Food Industry: History, Evolution and Current Trend. Bachelor's Thesis, Luiss Guido Carli University, Rome, Italy, 2015.

9. Bardi, A.; Schwartz, S.H. Values and Behavior: Strength and Structure of Relations. Personal. Soc. Psychol. Bull. 2003, 29, 1207-1220. [CrossRef]

10. Antwi, A.O.; Matsui, K. Consumers' Food Value Attributes on Ghana's Local Market; Case Study of Berekum Municipality. Int. J. Environ. Agric. Biotechnol. 2018, 3, 834-838. [CrossRef]

11. Bazzani, C.; Gustavsen, G.W.; Nayga, R.M.; Rickertsen, K. A comparative study of food values between the United States and Norway. Eur. Rev. Agric. Econ. 2018, 45, 239-272. [CrossRef]

12. Templier, M.; Paré, G. A Framework for Guiding and Evaluating Literature Reviews. Commun. Assoc. Inf. Syst. 2015, 37, 112-137. [CrossRef]

13. Levy, Y.; Ellis, T.J. A Systems Approach to Conduct an Effective Literature Review in Support of Information Systems Research. Inf. Sci. Int. J. Emerg. Transdiscipl. 2006, 9, 181-212. [CrossRef]

14. Rousseau, D.M.; Manning, J.; Denyer, D. 11 Evidence in Management and Organizational Science: Assembling the Field's Full Weight of Scientific Knowledge Through Syntheses. Acad. Manag. Ann. 2008, 2, 475-515. [CrossRef]

15. Tranfield, D.; Denyer, D.; Smart, P. Towards a Methodology for Developing Evidence-Informed Management Knowledge by Means of Systematic Review. Br. J. Manag. 2003, 14, 207-222. [CrossRef]

16. Dagevos, H.; van Ophem, J. Food consumption value. Br. Food J. 2013, 115, 1473-1486. [CrossRef] 
17. Hobbs, J.E. The COVID-19 pandemic and meat supply chains. Meat Sci. 2021, 181, 108459. [CrossRef] [PubMed]

18. Liñán, J.; Arroyo, P.; Carrete, L. Conceptualizing Healthy Food: How Consumer's Values Influence the Perceived Healthiness of a Food Product. J. Food Nutr. Res. 2019, 7, 679-687. [CrossRef]

19. Beavers, A.W.; Atkinson, A.; Alaimo, K. How Gardening and a Gardener Support Program in Detroit Influence Participants' Diet, Food Security, and Food Values. J. Hunger. Environ. Nutr. 2019, 15, 149-169. [CrossRef]

20. Ditlevsen, K.; Denver, S.; Christensen, T.; Lassen, J. A taste for locally produced food - Values, opinions and sociodemographic differences among 'organic' and 'conventional' consumers. Appetite 2020, 147, 104544. [CrossRef]

21. Shahriari, E.; Torres, I.M.; Zúñiga, M.A.; Yarlou, P.M. Values Driving Organic Food Purchase Intention: A Comparative Analysis between a Developing Eastern Country (Iran) and a Developed Western Country (US). J. Int. Consum. Mark. 2019, 31, 317-329. [CrossRef]

22. Silva, E.; Klink, J.; McKinney, E.; Price, J.; Deming, P.; Rivedal, H.; Colquhoun, J. Attitudes of dining customers towards sustainability-related food values at a public university. campus. Renew. Agric. Food Syst. 2019, 35, 221-226. [CrossRef]

23. Lusk, J.L. External validity of the food values scale. Food Qual. Prefer. 2011, 22, 452-462. [CrossRef]

24. Lusk, J.L. Income and (Ir) rational food choice. J. Econ. Behav. Organ. 2019, 166, 630-645. [CrossRef]

25. Langellier, B.A.; Brookmeyer, R.; Wang, M.C.; Glik, D. Language use affects food behaviors and food values among Mexican-origin adults in the USA. Public Health Nutr. 2014, 18, 264-274. [CrossRef] [PubMed]

26. Ellison, B.; McFadden, B.; Rickard, B.J.; Wilson, N.L.W. Examining Food Purchase Behavior and Food Values During the COVID -19 Pandemic. Appl. Econ. Perspect. Policy 2020, 43, 58-72. [CrossRef]

27. Yang, Y.; Hobbs, J.E. Food values and heterogeneous consumer responses to nanotechnology. Can. J. Agric. Econ. 2020, 68, 289-313. [CrossRef]

28. Pérez-Villarreal, H.H.; Martínez-Ruiz, M.P.; Izquierdo-Yusta, A. Testing Model of Purchase Intention for Fast Food in Mexico: How do Consumers React to Food Values, Positive Anticipated Emotions, Attitude toward the Brand, and Attitude toward Eating Hamburgers? Foods 2019, 8, 369. [CrossRef]

29. Pérez-Villarreal, H.H.; Martínez-Ruiz, M.P.; Izquierdo-Yusta, A.; Gómez-Cantó, C.M. Food Values, Benefits and Their Influence on Attitudes and Purchase Intention: Evidence Obtained at Fast-Food Hamburger Restaurants. Sustainability 2020, 12, 7749. [CrossRef]

30. Tirelli, C.; Martínez-Ruiz, M.P.; Gómez-Ladrón-De-Guevara, R. Major influences on buying decision processes by international university students. Differences by continent of origin. Appetite 2013, 71, 104-112. [CrossRef]

31. Izquierdo-Yusta, A.; Gómez-Cantó, M.G.; Pelegrin-Borondo, J.; Martínez-Ruiz, M.P. Consumers' behavior in fast-food restaurants: a food value perspective from Spain. Br. Food 2019, 121, 386-399. [CrossRef]

32. Izquierdo-Yusta, A.; Gómez-Cantó, C.M.; Martínez-Ruiz, M.P.; Pérez-Villarreal, H.H. The influence of food values on postpurchase variables at food establishments. Br. Food J. 2020, 122, 2061-2076. [CrossRef]

33. Pappalardo, G.; Lusk, J.L. The role of beliefs in purchasing process of functional foods. Food Qual. Prefer. 2016, 53, 151-158. [CrossRef]

34. Pappalardo, G.; Carnemolla, T.M.; La Via, G. Factors affecting purchasing process of functional food. Calitatea 2016, 17, 229-235.

35. Ježovičová, K.; Turčínková, J.; Drexler, D. The Influence of Package Attributes on Consumer Perception at the Market With Healthy Food. Acta Univ. Agric. Et Silvic. Mendel. Brun. 2017, 64, 1919-1926. [CrossRef]

36. Muro-Rodríguez, A.I.; Pérez-Jiménez, I.R.; Esteban-Dorado, A.; Martínez-Ruiz, M.P. Food Values, Satisfaction, and Loyalty: Some Evidence in Grocery Retailing Acquired during the COVID-19 Pandemic. Sustainability 2021, 13, 3908. [CrossRef]

37. Suzuki, T.; Oishi, T.; Kurokura, H.; Yagi, N. Which Aspects of Food Value Promote Consumer Purchase Intent after a Disaster? A Case Study of Salmon Products in disaster-affected Areas of the Great East Japan Earthquake. Foods 2019, 8, 14. [CrossRef] [PubMed]

38. Tohtubtiang, K. Anuntoavoranich Factors determining value and consumption of Thai food: a structural model. Int. Food Res. J. 2017, 24, 1383-1386.

39. Kim, S.S.; Choe, J.Y.; Lee, S. How are food value video clips effective in promoting food tourism? Generation $\mathrm{Y}$ versus nonGeneration Y. J. Travel Tour. Mark. 2017, 35, 377-393. [CrossRef]

40. Yang, S.H.; Panjaitan, B.P.; Ujiie, K.; Wann, J.W.; Chen, D. Comparison of food values for consumers' preferences on imported fruits and vegetables within Japan, Taiwan, and Indonesia. Food Qual. Prefer. 2021, 87, 104042. [CrossRef]

41. Tam, R.; Yassa, B.; Parker, H.; O'Connor, H.; Allman-Farinelli, M. University students' on-campus food purchasing behaviors, preferences, and opinions on food availability. Nutrition 2017, 37, 7-13. [CrossRef] [PubMed]

42. Engel, E. Die Productions-und Consumtionsverhaltnisse des KBnigreichs Sachsen. In Zeitschrifr des Statistischen Biireaus des Koniglich Sachsischen Ministeriums des Innern; Königlich Sächsisches Statistisches Bureau: Leipzig, Germany, 1857; pp. 1-54.

43. Chai, A.; Rohde, N.; Silber, J. Measuring the diversity of household spending patterns. J. Econ. Surv. 2014, 29, 423-440. [CrossRef]

44. Clements, K.W.; Si, J. Engel's Law, Diet Diversity, and the Quality of Food Consumption. Am. J. Agric. Econ. 2017, 100, 1-22. [CrossRef]

45. Schnepf, R. Consumers and Food Price Inflation. Congressional Research Service, Library of Congress. Available online: https:/ / sgp.fas.org/crs/misc/R40545.pdf (accessed on 22 September 2021).

46. Filieri, R. Consumer co-creation and new product development: a case study in the food industry. Mark. Intell. Plan. 2013, 31, 40-53. [CrossRef] 
47. Conner, M.; Armitage, C.J. Social psychological models of food choice. In The Psychology of Food Choice; Shepherd, R., Raats, M., Eds.; CABI Publishing: Walingford, UK, 2006.

48. United Nations (UN). 2020. Available online: https://www.un.org/sustainabledevelopment/development-agenda/ (accessed on 10 August 2021).

49. Stafford-Smith, M.; Griggs, D.; Gaffney, O.; Ullah, F.; Reyers, B.; Kanie, N.; Stigson, B.; Shrivastava, P.; Leach, M.; O'Connell, D. Integration: The key to implementing the sustainable development goals. Sustain. Sci. 2017, 12, 911-919. [CrossRef] [PubMed] 